\title{
Sonic Hedgehog Promotes the Survival of Specific CNS Neuron Populations and Protects These Cells from Toxic Insult In Vitro
}

\author{
Ningning Miao, Monica Wang, Jennifer A. Ott, Josephine S. D'Alessandro, Tod M. Woolf, David A. Bumcrot, \\ Nagesh K. Mahanthappa, and Kevin Pang
}

Ontogeny, Inc., Cambridge, Massachusetts 02138

\begin{abstract}
Sonic hedgehog (Shh), an axis-determining secreted protein, is expressed during early vertebrate embryogenesis in the notochord and ventral neural tube. In this site it plays a role in the phenotypic specification of ventral neurons along the length of the CNS. For example, Shh induces the differentiation of motor neurons in the spinal cord and dopaminergic neurons in the midbrain. Shh expression, however, persists beyond this induction period, and we have asked whether the protein shows novel activities beyond phenotype specification. Using cultures derived from embryonic day 14.5 (E14.5) rat ventral mesencephalon, we show that Shh is also trophic for dopaminergic neurons. Interestingly, Shh not only promotes dopaminergic neuron survival, but also promotes the survival of midbrain GABA-immunoreactive (GABA-ir) neurons. In cultures derived
\end{abstract}

from the E15-16 striatum, Shh promotes the survival of GABA-ir interneurons to the exclusion of any other cell type. Cultures derived from E15-16 ventral spinal cord reveal that Shh is again trophic for interneurons, many of which are GABA-ir and some of which express the Lim-1/2 nuclear marker, but it does not appear to support motorneuron survival. Shh does not support the survival of sympathetic or dorsal root ganglion neurons. Finally, using the midbrain cultures, we show that in the presence of $\mathrm{MPP}^{+}$, a highly specific neurotoxin, Shh prevents dopaminergic neuron death that normally would have occurred. Thus Shh may have therapeutic value as a protective agent in neurodegenerative disease.

Key words: Sonic hedgehog; patched; midbrain; striatum; spinal cord; Parkinson's disease
In Drosophila, the hedgehog gene was first discovered for the role it plays in early embryo patterning (Nusslein-Volhard and Wieschaus, 1980). Further study showed that the product of this gene is secreted and as an intercellular signaling protein plays a critical role in body segmentation and patterning of imaginal disk derivatives such as eyes and wings (Lee et al., 1992; Mohler and Vani, 1992; Tabata et al., 1992). There are, at present, three mammalian homologs of Drosophila hedgehog protein that have been identified: Sonic hedgehog (Shh), Desert hedgehog, and Indian hedgehog (Fietz et al., 1994). During the course of vertebrate development, these secreted peptide molecules are involved in axial patterning and consequently regulate the phenotypic specification of precursor cells into functional differentiated cells.

The embryonic expression pattern of Shh has been shown to be closely linked to the development and differentiation of the entire ventral neuraxis (Marti et al., 1995a). Using naive neural tube explants derived from the appropriate levels of the rostrocaudal axis, it has been demonstrated that the induction of spinal motor neurons (Roelink et al., 1994; Tanabe et al., 1995), midbrain dopaminergic neurons (Hynes et al., 1995; Wang et al., 1995), and basal forebrain cholinergic neurons (Ericson et al., 1995) are dependent on exposure to Shh. This molecule appears to be crucial for such patterning and phenotype specification in vivo, because mouse embryos deficient in the expression of functional Shh gene product manifest a lack of normal ventral patterning in

Received Feb. 26, 1997; revised May 16, 1997; accepted May 20, 1997.

We thank Drs. D. Melton, T. Jessell, C. Tabin, and T. Ingolia for critical review of this manuscript; A. McMahon and M. Scott for in situ probe templates; A. McMahon and T. Jessell for antibodies; and H. Roelink for Shh-encoding baculovirus. We also thank P. Jin for advice on QC-PCR.

Correspondence should be addressed to Kevin Pang, Ontogeny, Inc., 45 Moulton Street, Cambridge, MA 02138.

Copyright (C) 1997 Society for Neuroscience $0270-6474 / 97 / 175891-09 \$ 05.00 / 0$ the CNS as well as gross atrophy of the entire cranium (Chiang et al., 1996) .

In this study we have explored the issue of whether Shh may have activities at stages in neural development later than those studied previously. Namely, we have asked whether Shh is trophic for particular neural populations, and under toxic conditions, whether Shh is neuroprotective. Using cultures derived from the embryonic day 14-16 (E14-16) rat, we find that Shh is trophic for midbrain, striatal, and spinal neurons. In the first case the factor is trophic for both dopaminergic and GABA-immunoreactive (GABA-ir) neurons. From the striatum, the surviving neurons are exclusively GABA-ir, whereas in the spinal cultures Shh promotes survival of a heterogeneous population of putative interneurons. Shh does not support survival of any peripheral nervous system neurons tested. Finally, we show that Shh protects cultures of midbrain dopaminergic neurons from the toxic effects of $\mathrm{MPP}^{+}$, a specific neurotoxin that induces Parkinsonism in vivo. Together, these observations indicate a novel role for Shh in nervous system development and its potential role as a therapeutic.

\section{MATERIALS AND METHODS}

Whole-mount in situ hybridization. Whole-mount in situ hybridization on bisected E14.5 Sprague Dawley rat embryos was performed with digoxigenin-labeled (Boehringer Mannheim, Indianapolis, IN) mouse RNA probes as described previously (Wilkinson, 1992). Bound probe was detected with alkaline phosphatase-conjugated anti-digoxigenin Fab fragments (Boehringer Mannheim). The $0.7 \mathrm{~kb}$ Shh probes were transcribed using T3 (antisense) or T7 (sense) RNA polymerase from HindIII (antisense) or BamHI (sense) linearized templates as described by Echelard et al. (1993). The $0.9 \mathrm{~kb}$ Ptc probes were transcribed using T3 (antisense) or T7 (sense) RNA polymerase from BamHI (antisense) or HindIII (sense) linearized templates as described by Goodrich et al. (1996).

Shh protein and anti-Shh antibody. Rat Sonic hedgehog amino terminal signaling domain (amino acids 2-198) (Porter et al., 1995) was cloned into a baculovirus expression vector (Invitrogen, San Diego, CA) (virus 
encoding Shh insert was a gift of Dr. Henk Roelink, University of Washington). High Five insect cells (Invitrogen) were infected with the baculovirus according to manufacturer's instructions. The culture supernatant was batch-adsorbed to heparin agarose type I (Sigma, St. Louis, $\mathrm{MO}$ ), and Shh was eluted with PBS containing a total of $0.75 \mathrm{M} \mathrm{NaCl}$ and $0.1 \mathrm{~mm} \beta$-mercaptoethanol. Shh concentration was determined by the method of Ericson et al. (1996). Escherichia coli-derived Shh was obtained as described previously (Wang et al., 1995) and purified as described above. All samples were sterile-filtered, and aliquots were frozen in liquid nitrogen. Anti-Shh polyclonal antibody was a gift from Dr. Andy McMahon (Harvard University). Preparation of this reagent, directed against the amino peptide of Shh, is described by Bumcrot et al. (1995). Anti-Shh monoclonal antibody (5E1) was a gift of Dr. Thomas Jessell (Columbia University), and preparation of this reagent is described by Ericson et al. (1996).

Dissociation and culture of neural tissue. E14.5 rat ventral mesencephalon was dissected as described by Shimoda et al. (1992). Striatal cultures were established from E15-16 embryos from the regions identified by Altman and Bayer (1995) as the striatum and pallidum. Spinal cultures used the ventral one-third of the E15-16 spinal cord (Camu and Henderson, 1992). Tissues were dissociated for $\sim 30 \mathrm{~min}$ in $0.10-0.25 \%$ trypsin-EDTA (Life Technologies, Gaithersburg, MD), and the digestion was stopped using an equal volume of $\mathrm{Ca}^{2+} / \mathrm{Mg}^{2+}$-free HBSS (Life Technologies) containing $2.5 \mathrm{mg} / \mathrm{ml}$ soybean trypsin inhibitor (Sigma) and $0.04 \%$ DNase (Grade II, Boehringer Mannheim). Cells were than plated at $1 \times 10^{5}$ to $2 \times 10^{5}$ cells/well in the medium of Krieglstein et al. (1995) (a modified N2 medium) in 24-well tissue culture plates (Falcon) coated with poly-L-lysine or poly-L-ornithine (Sigma) after one wash in the same medium. Note that this procedure results in cultures in which the cells have never been exposed to serum and stands in contrast to cultures in which serum has been used to neutralize dissociation proteases or to initially "prime" the cells before serum withdrawal. The following peptide growth factors were added as indicated in the results: basic fibroblast growth factor, transforming growth factor $\beta 1$ (TGF $\beta 1$ ), TGF $\beta 2$, glial-derived neurotrophic factor (GDNF), and brain-derived neurotrophic factor (BDNF) (all from PeproTech, Rocky Hill, NJ; additional lots of BDNF and GDNF were purchased from Promega, Madison, WI). Anti-TGF $\beta$ antibodies were purchased from R \& D Systems (Minneapolis, MN). Antibody was added at the time of Shh addition to the cultures. Cultures were maintained for up to 2 weeks, and the medium was changed every $3 \mathrm{~d}$.

Immunoctyochemistry and cell scoring. For all cell staining, cultures were fixed with $4 \%$ paraformaldehyde in PBS (plus $0.1 \%$ glutaraldehyde if staining for GABA) and blocked using $2 \%$ goat serum (Sigma), $0.5 \%$ Triton X-100 in PBS. Antibody incubations were performed in the blocking solutions. Antibodies used in this study were anti-tubulin $\beta$ III (Sigma), anti-tyrosine hydroxylase (TH) (Boehringer Mannheim and Sigma), anti-GABA (Sigma), and anti-glial fibrillary acidic protein (GFAP) (Sigma). Primary antibodies were detected using horseradish peroxidase-, alkaline phosphatase- (Vector, Burlingame, CA), or fluorochrome-conjugated secondary antibodies (Jackson Immunoresearch, West Grove, PA). Peroxidase-linked secondaries were visualized using an Ni/DAB kit (Zymed, South San Francisco, CA), and phosphatase-linked secondaries were visualized using Vector Blue (Vector).

Cell counting was performed using an Olympus inverted microscope at a total magnification of $200 \times$. Data presented are representative and have been confirmed by repeating the cultures at least 3-10 independent times for each neural population discussed. Cell numbers are reported as cells/field (the average of 20-40 fields from a total of 4 wells/condition; 3-10 independent experiments were assessed for each culture condition examined). Consistency of counting was verified by at least two observers. Errors are reported as SEM, and significance is calculated by Student's $t$ test.

Measurement of dopamine (DA) transport. To detect the presence of the DA transporter (Cerruti et al., 1993; Ciliax et al., 1995), cultures were incubated with a mixture consisting of $5 \times 10^{-8} \mathrm{M}{ }^{3} \mathrm{H}-\mathrm{DA}$ (Amersham, Arlington Heights, IL; $48 \mathrm{Ci} / \mathrm{mmol}$ ), $100 \mu \mathrm{M}$ ascorbic acid (Sigma), $1 \mu \mathrm{M}$ fluoxetine (Eli Lilly, Indianapolis, IN), $1 \mu \mathrm{M}$ desmethylimipramine (Sig$\mathrm{ma}$ ), and $10 \mu \mathrm{M}$ pargyline (Sigma) in DME-F12. Nonspecific labeling was measured by the addition of $5 \times 10^{-5} \mathrm{M}$ unlabeled DA. Cells were incubated for $30 \mathrm{~min}$ at $37^{\circ} \mathrm{C}$, rinsed three times with PBS, and processed for either scintillation counting or autoradiography. For scintillation counting, cells were first lysed with $150 \mu \mathrm{l}$ of $0.1 \%$ SDS and then added to $500 \mu \mathrm{l}$ of Microscint 20 (Packard, Meridian, CT) and counted in a
Packard Instrument Topcount scintillation machine. For autoradiography, sister plates were coated with NTB-2 autoradiographic emulsion (Kodak, Rochester, NY) that had been diluted 1:3 with $10 \%$ glycerol. The plates were then air-dried, exposed for 1-2 weeks, and developed.

Quantitative competitive PCR (QC-PCR). RNA was isolated from cells and tissue using Trizol (Life Technologies) as prescribed by the manufacturer. Genomic DNA was removed from the RNA by incubation with $0.5 \mathrm{U}$ of DNase (Life Technologies) at room temperature for $15 \mathrm{~min}$. The solution was heated to $65^{\circ} \mathrm{C}$ for $10 \mathrm{~min}$ to inactivate the DNase. Reverse transcription was performed using random hexamer and MuLV reverse transcriptase (RT) (Life Technologies) as suggested by the manufacturer. All of the quantitative RT-PCR internal controls, or mimics, were synthetic single-stranded DNA oligonucleotides corresponding to the target sequence with an internal deletion from the central region (Oligos, Etc., Wilsonville, OR). For actin, target $=180 \mathrm{bp}$, mimic $=130 \mathrm{bp}$; for $p t c$, target $=254 \mathrm{bp}$, mimic $=100 \mathrm{bp}$. PCR was performed using the Clontech PCR kit; for actin: annealing temperature $54^{\circ} \mathrm{C}$, oligos GGCTCCGGTATGTGC, GGGGTACTTC-AGGGT; for $p t c$ : annealing temperature $62^{\circ} \mathrm{C}$, oligos CATTGGCAGG-AGGAGTTGATTGTGG, AGCACCTTTTGAGTGGAGTTTGGGG. In each QC-PCR reaction, four reactions were set up with equal amounts of sample cDNA in each tube and fourfold serial dilution of mimic. Also, for each sample, an aliquot of cDNA was saved and amplified along with quantitative PCR as control for contamination. PCR reactions were performed in an MJ Research PTC-200 thermal cycler, and the following cycling profile was used: $95^{\circ} \mathrm{C}$ for $35 \mathrm{sec}, 54^{\circ}$ or $62^{\circ} \mathrm{C}$ for $25 \mathrm{sec}, 72^{\circ} \mathrm{C}$ for $20 \mathrm{sec}$, for $30 \mathrm{cycles}$. The reaction mixtures were then fractionated by agarose electrophoresis, negative films were obtained, and the films were digitally scanned and quantified by area integration according to established procedures (Wang et al., 1995, and references therein). The quantity of target molecules was normalized to the competing mimic and expressed as a function of cDNA synthesized and used in each reaction.

$\mathrm{N}$-methyl-4-phenylpyrridinium $\left(\mathrm{MPP}^{+}\right)$administration. Culture and $\mathrm{MPP}^{+}$treatment of dopaminergic neurons were performed as described previously (Hyman et al., 1994; Krieglstein et al., 1995). $\mathrm{MPP}^{+}$(Aldrich, St. Louis, MO) was added at day 2 of culture to a final concentration of $2 \mu \mathrm{M}$ for $48 \mathrm{hr}$. Cultures were then washed extensively to remove $\mathrm{MPP}^{+}$, cultured for an additional $24-48 \mathrm{hr}$ to allow clearance of dying $\mathrm{TH}^{+}$ neurons, and then processed for immunocytochemistry.

\section{RESULTS}

\section{Shh and Ptc continue to be expressed in the rat CNS after the major period of dorsoventral patterning}

Previous studies have shown that $s h$ is expressed in the vertebrate embryo in the period during which dorsoventral patterning manifests (approximately E9-10 in the rat). Within the CNS, shh expression persists beyond this period and can be detected at a very high level in the E14-16 rat embryo. For example, in situ hybridization studies of the E14.5 embryo (Fig. $1 A, E$ ) reveal that $s h h$ is expressed in ventral regions of the spinal cord, hindbrain, midbrain, and diencephalon. Lower levels of expression are observed in the ventral striatum and septum, whereas no expression is observed in the cortex within the limits of detection of this method. Interestingly, a "streak" of $s h$ expression (Fig. $1 A$, arrow) is observed to bisect the diencephalon into rostral and caudal halves. This is likely to be the zona limitans intrathalamica that separates prosomeres 2 and 3 and has been observed previously in the studies of shh expression in the developing chick embryo (Marti et al., 1995b).

Recent biochemical evidence supports the view that the ptc gene product can act as a high affinity Shh receptor (Marigo et al., 1996a; Stone et al., 1996). Ptc shows an expression pattern complementary to that of $s h$ (Fig. $1 C, E$ ) and is observed primarily lateral and dorsal to the sites of $s h$ expression. The complementarity of expression is most dramatic in the diencephalon, where ptc mRNA is absent from the zona limitans (Fig. 1C, double arrow), but is expressed at a very high level on either side of this structure. Of further interest is the observation that rostral of the zonal limitans, ptc expression no longer seems as restricted to 

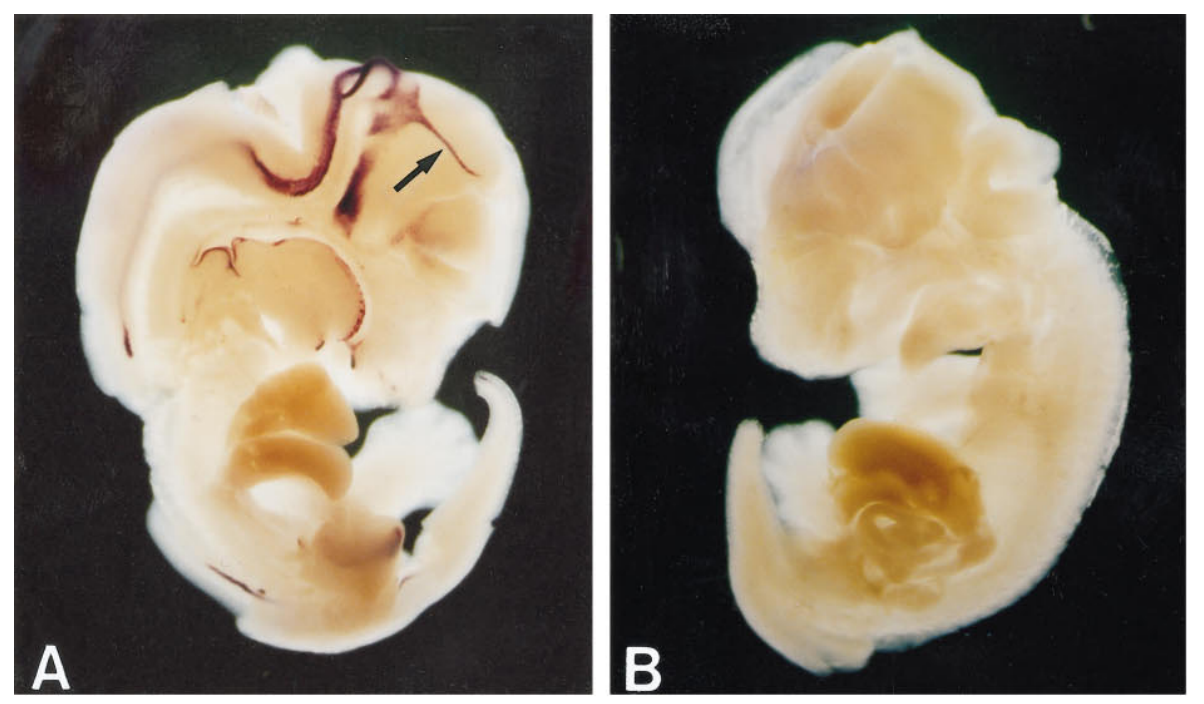

E
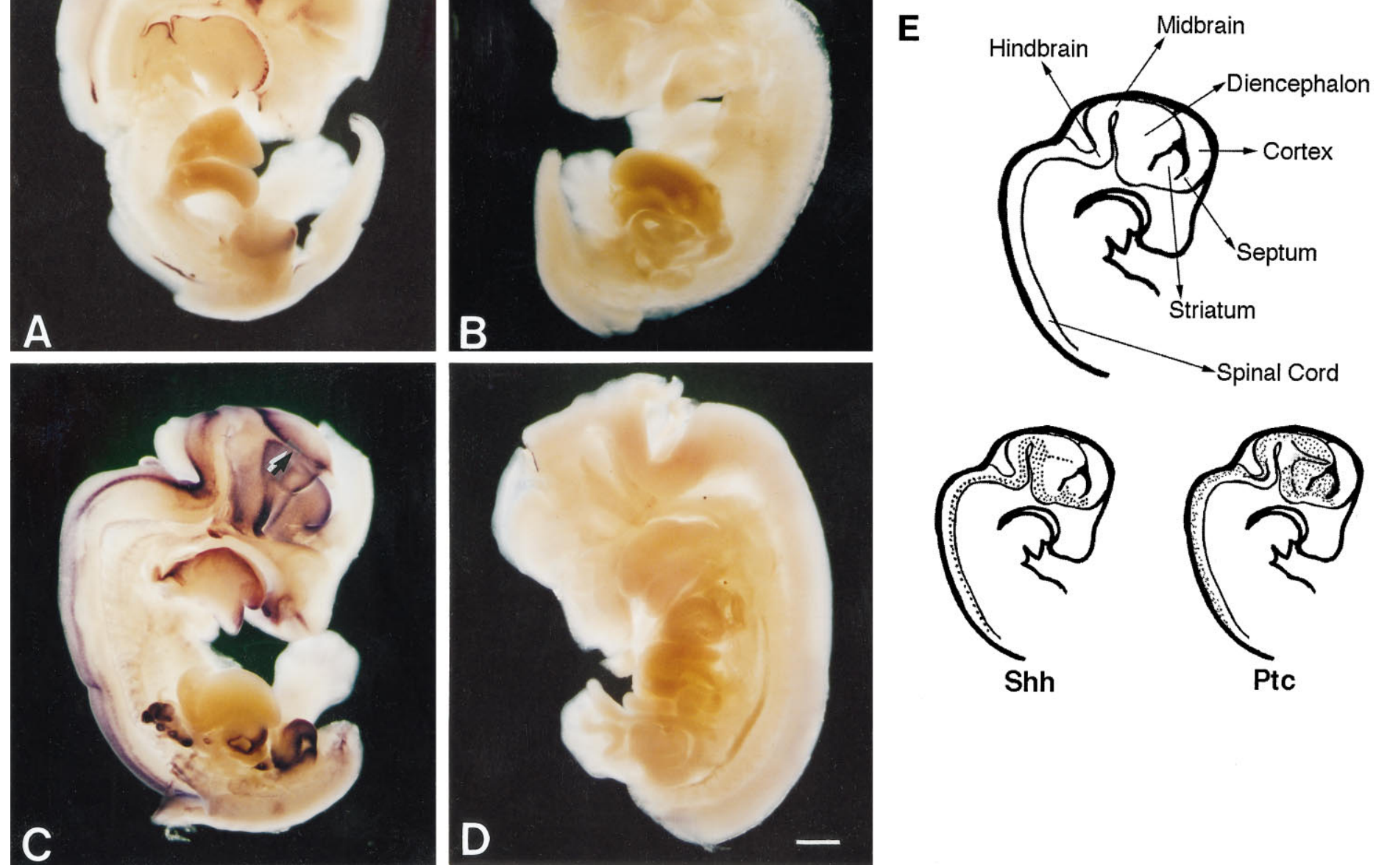

Figure 1. Shh and Ptc in the E14.5 rat embryo. Shh ( $A$, antisense; $B$, sense control), and ptc (C, antisense; $D$, sense control) expression as detected by in situ hybridization with digoxigenin-labeled riboprobes and alkaline phosphatase-conjugated anti-digoxigenin. The arrow in $A$ and the double arrow in $C$ designate the zona limitan intrathalamica. Major anatomical structures and summary diagrams of shh and $p t c$ expression are shown in $E$. Scale bar, $1 \mathrm{~mm}$.

regions immediately dorsal of $s h$ expression. Again, within the detection limits of this technique, ptc is not expressed in the cortex. Thus in regions where $s h$ is expressed, adjacent tissue appears capable of responding to the gene product, as evidenced by expression of the putative receptor.

\section{Shh promotes dopaminergic neuron survival}

In the developing midbrain (approximately E9), Shh was first characterized for its ability to induce the production of dopaminergic neurons. Thus the trophic potential of Shh was tested on this neuronal population at a stage when these neurons have already been induced. Using cultures derived from the E14.5 mesencephalon, we found that Shh increases the survival of $\mathrm{TH}^{+}$ neurons in a dose-dependent manner (Fig. 2A). These cells exhibited a neuronal morphology (Fig. $2 C, E$ ), and $>95 \%$ of the $\mathrm{TH}^{+}$cells were also positive for the neuron-specific marker tubulin $\beta$ III (Banerjee et al., 1990); GFAP staining revealed no glial cells (data not shown). Differences in $\mathrm{TH}^{+}$neuron survival between control and Shh-treated wells could be observed as early as day 4 . Note that under these stringently serum-free conditions (i.e., at no time were the cells exposed to serum), baseline levels of survival are even lower than those conventionally reported for cultures that have been maintained in low serum or that have been briefly serum-"primed". By 2 weeks in culture, $<5 \%$ of the total $\mathrm{TH}^{+}$cells plated were present in the control condition, whereas $25-30 \%$ survive in $50 \mathrm{ng} / \mathrm{ml}$ of Shh (from 4 to $14 \mathrm{~d}$; $p<$ 0.001 at 25 and $50 \mathrm{ng} / \mathrm{ml}$ ).

All catecholaminergic neurons express TH, but the presence of a specific high-affinity DA uptake system is indicative of midbrain dopaminergic neurons (Di Porzio et al., 1980; Denis-Donini et al., 1984; Cerruti et al., 1993; Ciliax et al., 1995). As further evidence that the cells supported by Shh are bona fide dopaminergic neurons, specific, high-affinity DA uptake was also demonstrated (Fig. 3). Midbrain cultures treated with Shh transported and retained ${ }^{3} \mathrm{H}$-DA with a dose-response profile paralleling that of the survival curves (Fig. $3 A)(p<0.005$ at 25 and $50 \mathrm{ng} / \mathrm{ml})$. Emulsion autoradiography also demonstrated that the cells taking up ${ }^{3} \mathrm{H}$-DA were neuronal in morphology (Fig. 3B). In addition, immunohistochemistry for DA itself demonstrated high cellular content (data not shown).

The observed effect of Shh on increased $\mathrm{TH}^{+}$neuron number 

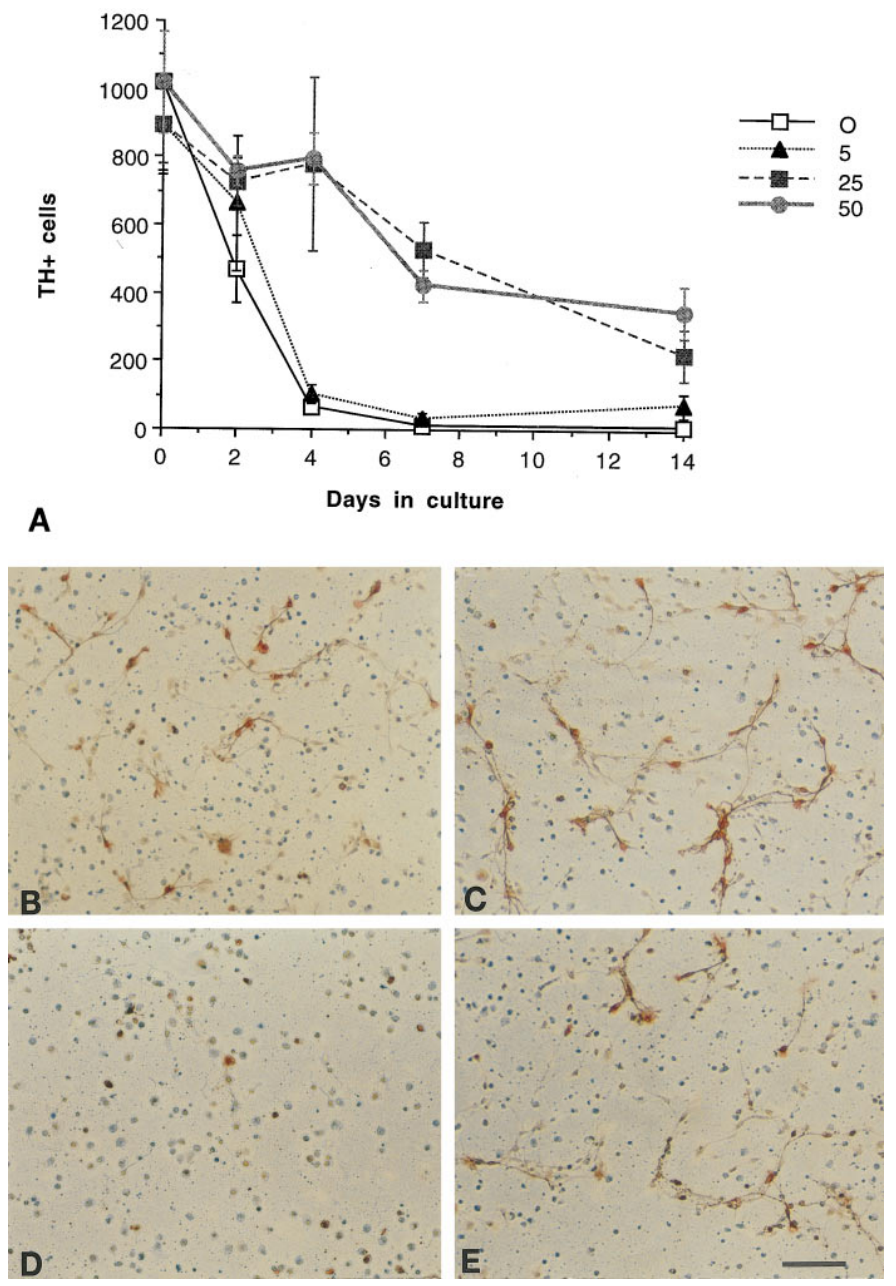

Figure 2. Shh promotes the survival of $\mathrm{TH}^{+}$neurons of the ventral mesencephalon. $A$, Time course and dose-response of the Shh effect. The number of $\mathrm{TH}^{+}$neurons in control cultures $(0 \mathrm{ng} / \mathrm{ml} \mathrm{Shh})$ began to decline dramatically by $4 \mathrm{~d}$ in vitro. In cultures treated with Shh at 25 and $50 \mathrm{ng} / \mathrm{ml}$, there were significantly greater numbers of $\mathrm{TH}^{+}$neurons over control through $14 \mathrm{~d}$ in vitro (from 4 to $14 \mathrm{~d}, p<0.001$ at 25 and $50 \mathrm{ng} / \mathrm{ml}$ ). The $50 \mathrm{ng} / \mathrm{ml}$ dose typically gave a $50-100 \%$ increase over controls at all time points (error bars represent SEM). Photomicrographs of $\mathrm{TH}^{+}$ neurons in control $(B, D)$ and $50 \mathrm{ng} / \mathrm{ml}$ Shh-treated $(C, E)$ cultures, $2 \mathrm{~d}(B$, $C)$ and $7 \mathrm{~d}(D, E)$ after plating. Note that in addition to an increased number of $\mathrm{TH}^{+}$cell bodies, the Shh-treated cells show extensive neuritic processes. Scale bar (shown in $E$ ): $200 \mu \mathrm{m}$.

is unlikely to be attributable to differentiation of latent progenitor cells, because previous studies demonstrated that the ability of Shh to induce dopaminergic neurons in explanted tissue is lost at later stages of development (Hynes et al., 1995; Wang et al., 1995). Furthermore, the effects are unlikely to be attributable to a mitogenic response of committed neuroblasts, because pulselabeling the cultures with 5-bromo-2'-deoxyuridine (BrdU) at 1 , 2 , or $4 \mathrm{~d}$ in vitro revealed very low mitotic activity in the presence or absence of Shh (data not shown). Thus, in addition to inducing dopaminergic neurons in the naive mesencephalon, Shh is a trophic factor for these neurons.

\section{Specificity of Shh action on midbrain neurons: regulated expression of $p t c$}

Expression of ptc has previously been shown to be regulated by Shh (Goodrich et al., 1996; Marigo et al., 1996b), and to date, Shh is the only factor known to transcriptionally upregulate ptc ex-

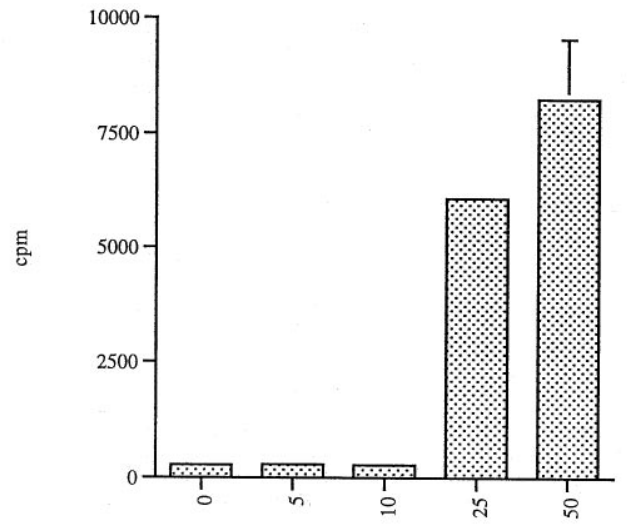

Shh(ng/ml)

A

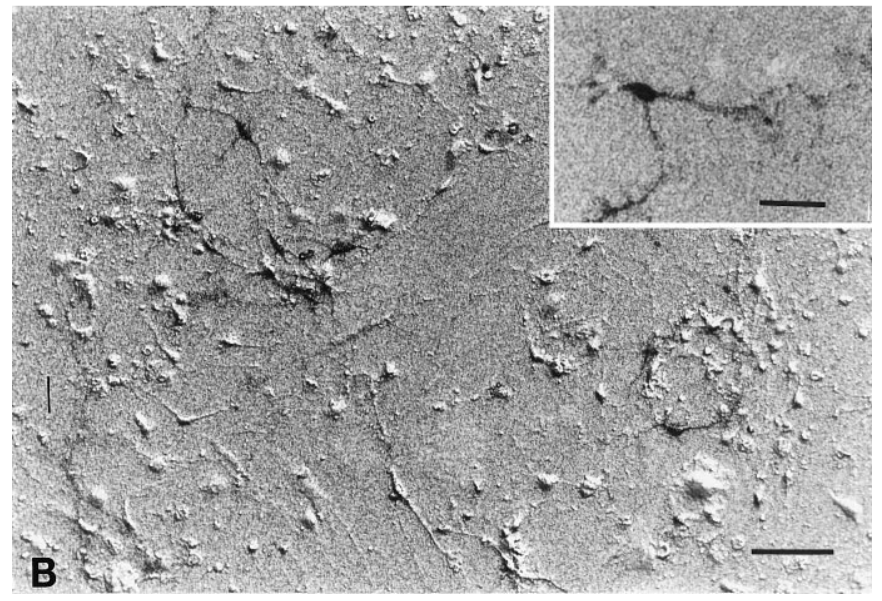

Figure 3. Transport of ${ }^{3} \mathrm{H}-\mathrm{DA}$. The identity and functionality of the surviving midbrain neurons was assessed by their ability to specifically transport DA. $A$, Addition of $25 \mathrm{ng} / \mathrm{ml}$ Shh resulted in a 22 -fold increase in ${ }^{3} \mathrm{H}$-DA cell uptake over controls and lower Shh concentrations; 50 $\mathrm{ng} / \mathrm{ml} \mathrm{Shh}$ gave a 30 -fold increase in ${ }^{3} \mathrm{H}$-DA uptake (error bars represent SD) $(p<0.005$ at 25 and $50 \mathrm{ng} / \mathrm{ml}) . B$, Autoradiography was performed on sister plates to visualize DA transport. Only cells with neuronal morphology transported ${ }^{3} \mathrm{H}$-DA (inset). Scale bar, $50 \mu \mathrm{m}$; inset, $15 \mu \mathrm{m}$.

pression. Therefore, the expression of ptc by mesencephalic explants would reinforce the view that these cells are capable of responding to Shh, and upregulation of ptc mRNA in response to Shh would strongly indicate the specificity of such a response. Therefore, QC-PCR was used to measure the level of ptc expression.

Ptc mRNA levels were measured at $0,2,4$, and $6 \mathrm{~d}$ of culture by the method described by Wang et al. (1995). For each culture condition at each time point, four separate cDNA samples were coamplified with a different known amount of mimic substrate (DNA that can be amplified by the same primers but yielding a product of molecular weight lower than that being sought in the sample). Thus for each condition and time point, a gel like that shown in Figure $4 A$ was generated (upper bands correspond to amplified ptc transcripts; lower bands correspond to amplified mimic). Using scanning densitometry to quantify the observed bands, a graph was produced for each sample (Fig. $4 B$ corresponds to $4 A$ ). When the density of the target band and the mimic band are equal, the concentration of the unknown target can be 


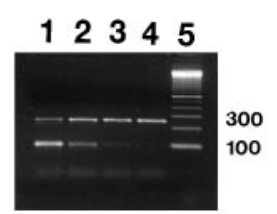

A

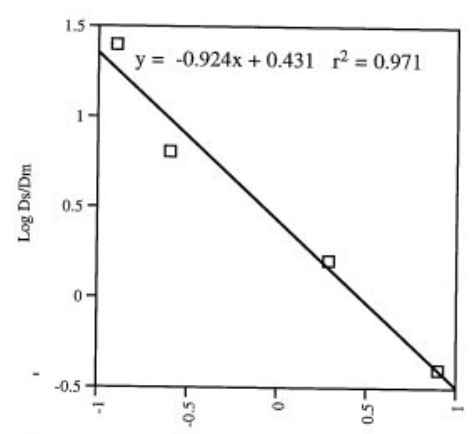

B

Log mimic
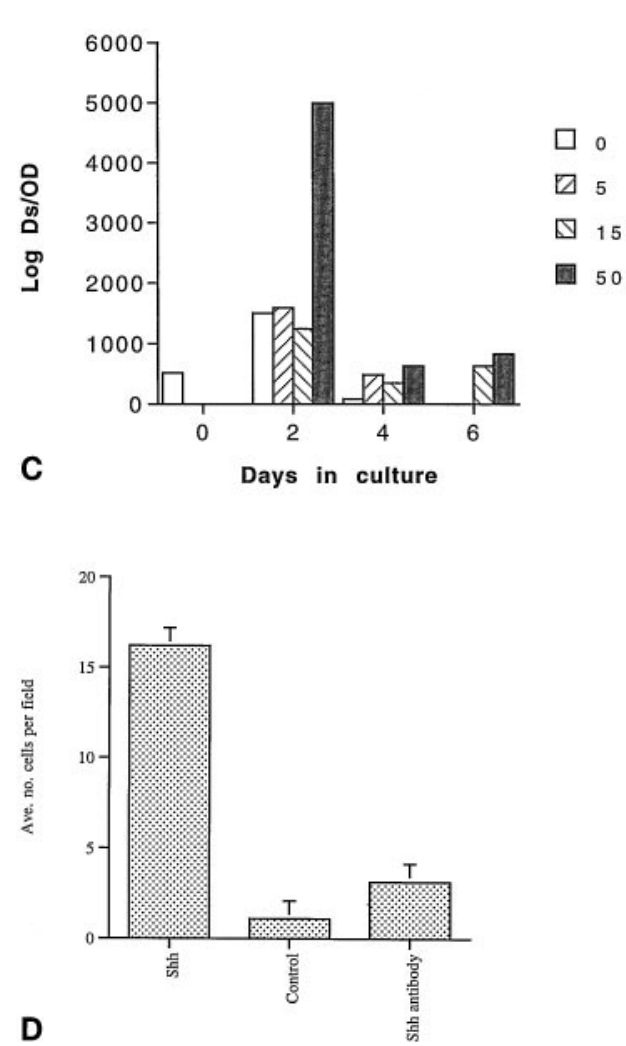

Figure 4. Specificity of Shh activity. A, QCPCR gel. Lanes 1-4 are cDNA from midbrain cultures that have been coamplified with successive fourfold dilutions of mimic oligo. Lane 5 is DNA marker lane. Ptc target is $254 \mathrm{bp}$ and mimic is 100 bp. $B$, Representative plot (corresponding to $A$ ) of the log concentration of competitive mimic versus the $\log$ of the obtained band densities of target and mimic PCR substrates demonstrates the linearity of the amplification reaction. The extrapolated value of $p t c$ message in the cDNA tested is determined to be equal to the value of mimic concentration where $\log D_{\mathrm{s}} / D_{\mathrm{m}}=0$. See main text for details of the procedure. Doses in $\mathrm{ng} / \mathrm{ml} ; D_{\mathrm{s}}=$ density of test substrate; $D_{\mathrm{m}}=$ density of competitive mimic. The $r^{2}$ value shows that determinations made within this range vary within $3 \%$. C, Administration of Shh induces ptc expression in a doseresponse that parallels the survival curve. The values are expressed as number of target molecules $\left(\log D^{s}\right)$ per total amount of cDNA used in each reaction as measured by optical density at $260 \mathrm{~nm}(O D)$ and were determined as demonstrated in $A$ and $B$. At $4 \mathrm{~d}$ in vitro Shh at 5 $\mathrm{ng} / \mathrm{ml}$ increases $p t c$ expression over control, and $50 \mathrm{ng} / \mathrm{ml}$ increases expression of ptc over the level found in the ventral mesencephalon at the time of dissection. $D$, Affinity-purified anti-Shh antibody inhibited the Shh neurotrophic response $(p<0.001)$. Cultures were maintained for $5 \mathrm{~d}$. Shh was added at a concentration of 50 $\mathrm{ng} / \mathrm{ml}$, and in the coadministration of Shh and anti-Shh ("Shh antibody") Shh was added at 50 $\mathrm{ng} / \mathrm{ml}$ and anti-Shh was added as a fivefold molar excess (error bars represent SEM). taken to be equal to the known concentration of mimic. Based on a linear curve fit, the concentration of mimic at the point at which the density of the mimic and the target substrate are equal (Log $\left.D_{\mathrm{s}} / D_{\mathrm{m}}=0\right)$ was taken to be the concentration of the substrate in the sample; this value was then normalized to the total amount of cDNA added to the reaction. These values are plotted in Figure $4 C$; correlation coefficients $\left(r^{2}\right)$ of the curve fits always exceeded 0.95 , and thus the margin of error for the values presented is $<5 \%$. This experiment was performed two independent times with independent cultures, and the results were nearly identical.

As shown in Figure $4 C$, significant ptc expression was observed in the E14.5 ventral mesencephalon (time 0). After $2 \mathrm{~d}$ of culture, higher levels of ptc expression were observed than at the time of dissection; in control cultures this might reflect the loss of ptc nonexpressing cell types, because a constant amount of RNA was analyzed. There was no difference in ptc expression between control cultures and those treated with either 5 or $15 \mathrm{ng} / \mathrm{ml}$ of Shh at this time; however, cultures treated with $50 \mathrm{ng} / \mathrm{ml}$ of Shh showed a 10 -fold induction of ptc mRNA expression relative to time of dissection and at least fourfold over other culture conditions. By $4 \mathrm{~d}$ of culture, ptc message levels had declined significantly in comparison to the $2 \mathrm{~d}$ level of expression, but high levels of expression were still observed in $50 \mathrm{ng} / \mathrm{ml} \mathrm{Shh}$. By $6 \mathrm{~d}$, no ptc expression was observed in either the control or $5 \mathrm{ng} / \mathrm{ml} \mathrm{Shh-}$ treated cultures, although actin could still be detected (data not shown). It is important to note that in the 15 and $50 \mathrm{ng} / \mathrm{ml}$ Shh-treated cultures, ptc expression matched or exceeded the time 0 expression of ptc in the mesencephalon despite the overall decrease in cell number. These results indicate that (1) ptc is expressed in the E14.5 ventral mesencephalon (confirming the observation made by in situ hybridization), (2) Shh is necessary for the maintenance of ptc gene expression, and (3) the expression of ptc shows an Shh dose dependence that parallels the neurotrophic activity described above.

\section{Specificity of Shh action on midbrain neurons: immunoneutralization}

As further evidence that the trophic activity of the Shh preparation used for these studies, purified from a baculovirus expression system, was attributable to Shh and not to a contaminating factor, antibody neutralization experiments were performed. As shown in Figure $4 D$, a saturating dose of Shh $(50 \mathrm{ng} / \mathrm{ml})$ promotes midbrain neuron survival $(p<0.001)$, whereas the same dose of Shh in the presence of a fivefold molar excess of activityneutralizing, anti-Shh, monoclonal antibody (5E1) [Ericson et al. (1996)] inhibits this trophic response $(p<0.001)$. In earlier studies (data not shown), an affinity-purified, polyclonal, anti-Shh antibody dramatically reduced the activity of Shh in the dopaminergic neuron survival assay $(p<0.005)$, whereas purified rabbit IgG antibody from preimmune sera had no significant effect. Anti-TGF $\beta$ antibodies used at a twofold molar excess to Shh did not inhibit the trophic activity, whereas they did inhibit the previously reported (Krieglstein et al., 1995) trophic effects of exogenously applied TGF $\beta$ s (data not shown). Addition of $\beta$-galactosidase, expressed and purified in a manner identical to Shh, failed to show any trophic effect (data not shown), and thus renders unlikely the possibility that an undefined baculovirus protein is responsible for the observed trophic effects. Finally, Shh purified from an E. coli expression system (Wang et al., 1995) also had trophic activity for $\mathrm{TH}^{+}$cells, whereas $\beta$-galactosidase purified identically to Shh from the $E$. coli expression system gave 


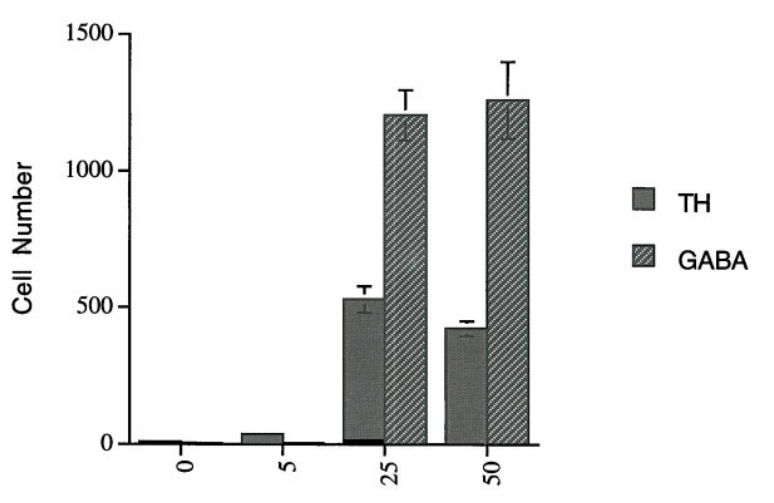

A

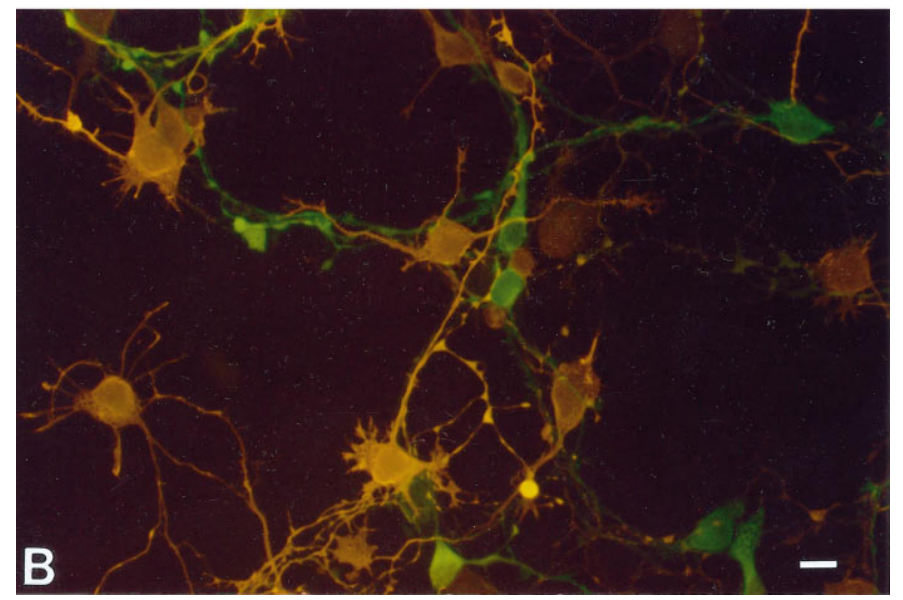

Figure 5. Shh supports the survival of midbrain $\mathrm{GABA}^{+}$neurons. $A$, In addition to supporting the survival of $\mathrm{TH}^{+}$cells in the midbrain cultures, Shh promotes the survival of GABA-ir neurons with a similar doseresponse (error bars represent SEM) (for TH, $p<0.001$ at 25 and 50 $\mathrm{ng} / \mathrm{ml}$; for GABA, $p<0.001$ at 25 and $50 \mathrm{ng} / \mathrm{ml}$ ). B, Double-label immunofluorescence of Shh-treated cultures shows that the majority of the GABA+ cells (orange) do not overlap with the $\mathrm{TH}^{+}$cells (green). Scale bar, $15 \mu \mathrm{m}$.

no such activity even at concentrations as high as $10 \mu \mathrm{g} / \mathrm{ml}$ (data not shown).

\section{Shh supports the survival of other midbrain neurons}

Because the original observations concerning the role of Shh in midbrain development were concerned with induction of dopaminergic neurons (Hynes et al., 1995; Wang et al., 1995), the current study initially focused on possible trophic effects on these neurons. Interestingly, the cultures in which the above described trophic effects were observed also demonstrated that the trophic effect of Shh extended to nondopaminergic neurons (i.e., $\mathrm{TH}^{-}$ neurons). Within the dopaminergic nucleus of the midbrain, the substantia nigra, GABA is also a major neurotransmitter (Masuko et al., 1992). Staining for GABA in these cultures (Fig. 5) showed that $\mathrm{GABA}^{+}$cells are supported by the presence of Shh, with a dose-response profile comparable to that of $\mathrm{TH}^{+}$cells. Furthermore, $\mathrm{GABA}^{+}$cells outnumber $\mathrm{TH}^{+}$cells by a ratio of $\sim 2: 1$. The two cell types together account for $\sim 95 \%$ of the total neurons as gauged by staining for tubulin $\beta$ III (data not shown), and thus it is clear that the trophic effect of Shh on midbrain

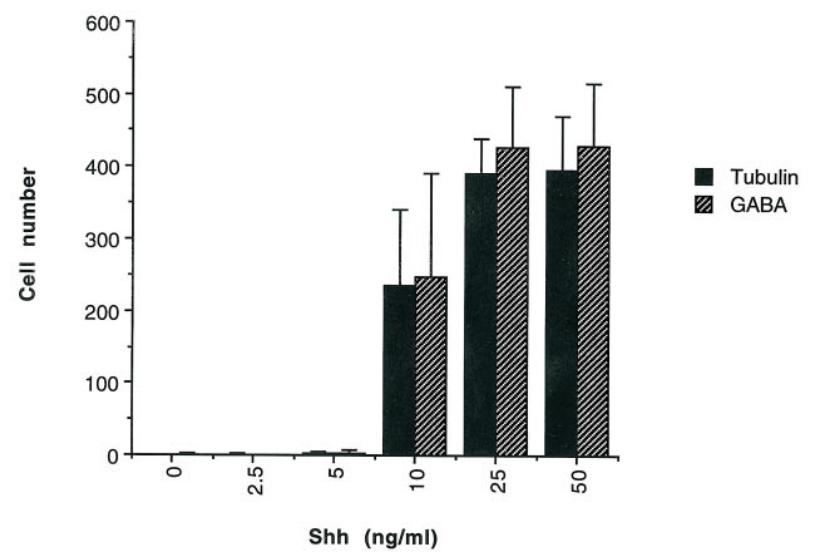

A

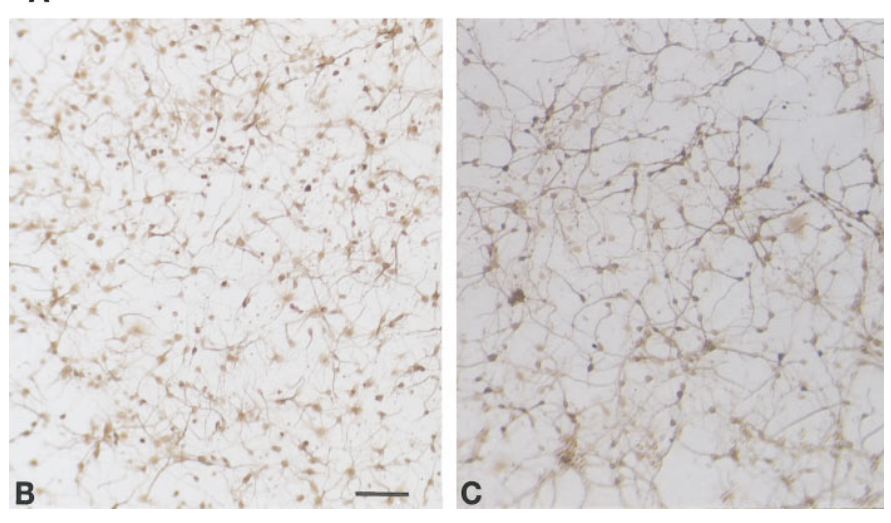

Figure 6. Shh effects on striatal cultures. $A$, At concentrations of 10 $\mathrm{ng} / \mathrm{ml}$ and higher, Shh promotes neuronal survival as gauged by staining for tubulin $\beta$ III, and these cells are exclusively $\mathrm{GABA}^{+}$(error bars represent SD) (tubulin $\beta \mathrm{III}, p<0.001$ at 25 and $50 \mathrm{ng} / \mathrm{ml}$; GABA, $p<$ 0.001 at 25 and $50 \mathrm{ng} / \mathrm{ml}$ ). Typical fields of neurons treated with $50 \mathrm{ng} / \mathrm{ml}$ Shh and stained for tubulin $\beta$ III $(B)$ and $\mathrm{GABA}^{+}(C)$ are shown. Scale bar, $100 \mu \mathrm{m}$.

neurons extends to multiple neuron subtypes (for TH, $p<0.001$ at 25 and $50 \mathrm{ng} / \mathrm{ml}$; for GABA, $p<0.001$ at 25 and $50 \mathrm{ng} / \mathrm{ml}$ ).

\section{Shh effects on striatal neurons}

Because Shh is strongly expressed in the ventral and lateral forebrain (Echelard et al., 1993; Ericson et al., 1995) and the Shh knockout mouse exhibits striatal defects (Chiang et al., 1996), Shh neurotrophic activity was examined in striatum-derived cultures as well. As assessed after $4 \mathrm{~d}$ in vitro (Fig. 6), Shh is a potent trophic factor for neurons cultured from the E15-16 striatum and shows a dose-response comparable to that of the midbrain. In comparing the number of total neurons (tubulin $\beta \mathrm{III}^{+}$cells) with that of $\mathrm{GABA}^{+}$neurons, it is clear that essentially all of the neurons supported by Shh are GABAergic (Fig. 6) (tubulin $\beta$ III, $p<0.001$ at 25 and $50 \mathrm{ng} / \mathrm{ml}$; GABA, $p<0.001$ at 25 and 50 $\mathrm{ng} / \mathrm{ml})$. That this effect is strictly trophic was confirmed by the observation that BrdU labeling indices over the course of the culture period were low and did not vary with dose (data not shown). Closer inspection reveals that the intensity of GABA staining is variable, and it is thus possible that various subtypes of $\mathrm{GABA}^{+}$interneurons (reviewed by Kawaguchi et al., 1995) are all supported by Shh.

\section{Shh effects on spinal neurons}

As a further examination of the postinductive effects of Shh on ventral neural tube derivatives, cultures of the E14-15 ventral neural tube were cultured with varying amounts of Shh. Again, 


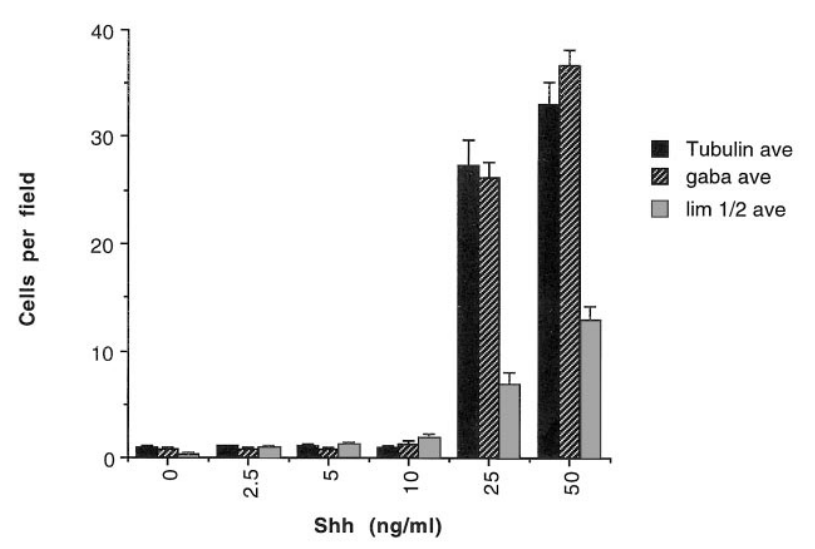

A

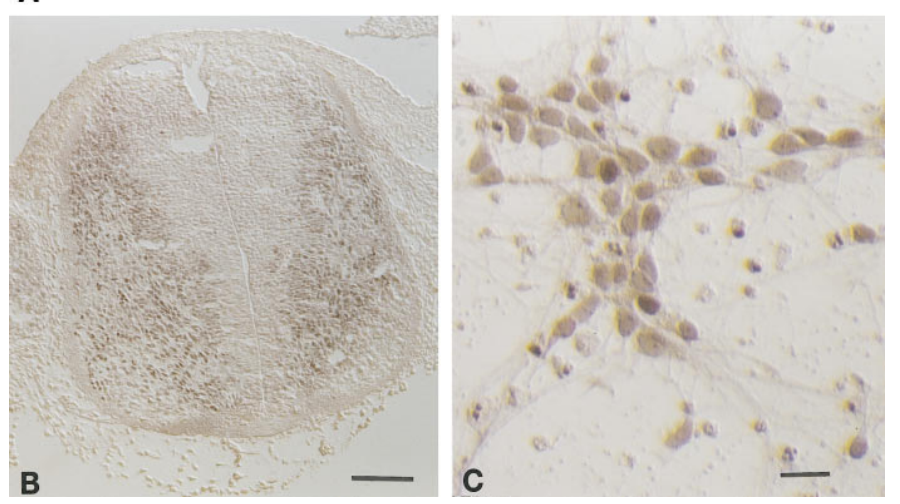

Figure 7. Shh effects on ventral spinal cultures. $A$, At concentrations of $25 \mathrm{ng} / \mathrm{ml}$ and higher, Shh promotes neuronal survival as gauged by staining for tubulin $\beta$ III. The majority of the cells stain positively for GABA, whereas a subset of cells stains for the nuclear marker of spinal interneurons Lim-1/2 (error bars represent SEM) (tubulin $\beta \mathrm{III}, p<0.001$ at 25 and $50 \mathrm{ng} / \mathrm{ml} ; \operatorname{lim~1/2,p<0.001~at~5,~10,~25,~and~} 50 \mathrm{ng} / \mathrm{ml} ; \mathrm{GABA}$, $p<0.001$ at 25 and $50 \mathrm{ng} / \mathrm{ml}$ ). Typical staining for Lim-1/2 in the E14 rat spinal cord $(B)$ (scale bar, $100 \mu \mathrm{m}$ ), and spinal neurons cultured in the presence of $50 \mathrm{ng} / \mathrm{ml} \mathrm{Shh}(C)$. Scale bar, $20 \mu \mathrm{m}$.

with a dose-response identical to that observed in the mesencephalic and striatal cultures, Shh promotes the survival of tubulin $\beta \mathrm{III}^{+}$neurons as scored after $4 \mathrm{~d}$ in vitro (Fig. $7 A$ ). A majority but not all of these cells also stain for GABA, and a smaller subset stain for a nuclear marker of spinal interneurons, Lim-1/2 (Tsuchida et al., 1994) (Fig. 7A-C) (tubulin $\beta I I I, p<0.001$ at 25 and $50 \mathrm{ng} / \mathrm{ml}$; Lim-1/2, $<<0.001$ at $5,10,25$, and $50 \mathrm{ng} / \mathrm{ml}$; $\mathrm{GABA}, p<0.001$ at 25 and $50 \mathrm{ng} / \mathrm{ml}$ ). It is important to note that although there is overlap between the $\mathrm{GABA}^{+}$and Lim-1/2 populations, the latter is not merely a subset of the former, because there are Lim- $1 / 2^{+}$cells that do not stain for GABA. Interestingly, immunoreactivity for the low-affinity nerve growth factor receptor (Camu and Henderson, 1992), Islet-1 (Ericson et al., 1992), or galectin-1 (Hynes et al., 1990), all markers of rat motorneurons, was not detectable in these cultures (although such staining could be demonstrated in acutely dissociated spinal preparations), and thus it appears that Shh is not trophic for spinal motorneurons.

\section{Shh protects $\mathrm{TH}^{+}$cells against MPP ${ }^{+}$toxicity}

The toxin 4-phenyl-1,2,3,6-tetrahydropterine (MPTP) and its active metabolite $\mathrm{MPP}^{+}$are selectively toxic to mesencephalic dopaminergic neurons (Kopin and Markey, 1988; Forno et al., 1993). Because other agents that promote survival of $\mathrm{TH}^{+}$cells also protect against chemical toxicity of $\mathrm{MPP}^{+}$(Hyman et al.,

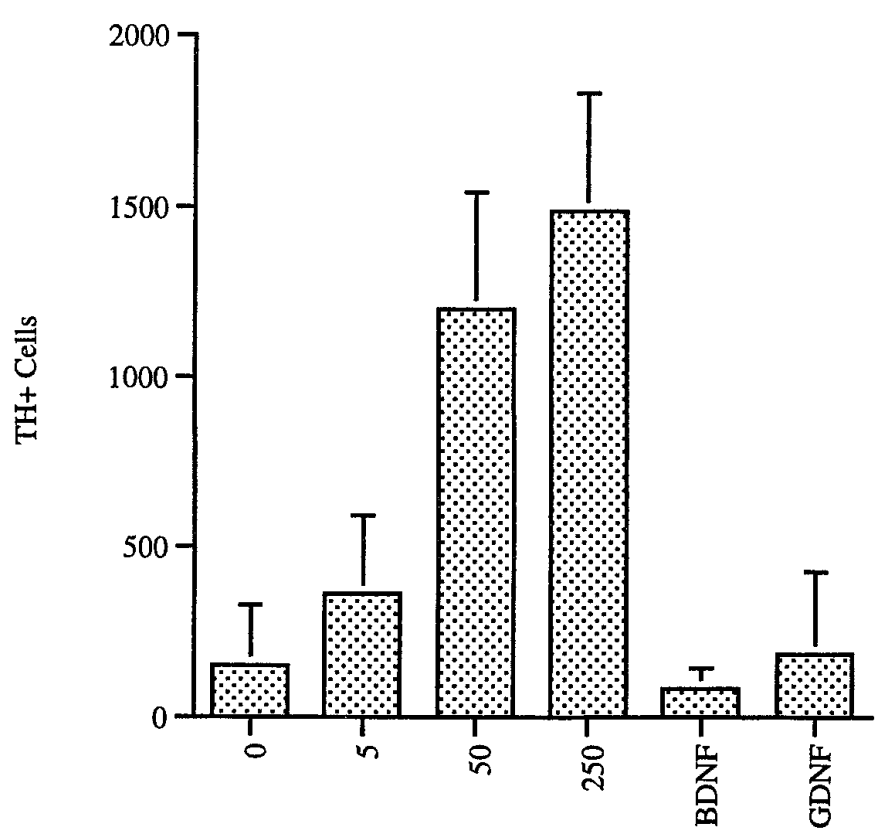

Figure 8. Shh protects midbrain $\mathrm{TH}^{+}$neurons from neurotoxic insult. Ventral mesencephalon neurons were cultured in the indicated concentrations of Shh $(\mathrm{ng} / \mathrm{ml})$. MPP ${ }^{+}$was added at $4 \mathrm{~d}$ in vitro for $48 \mathrm{hr}$. Cultures were then washed extensively and cultured for an additional $48 \mathrm{hr}$ to allow clearance of dying neurons. Protection from $\mathrm{MPP}^{+}$neurotoxicity could be seen at $5 \mathrm{ng} / \mathrm{ml}$, with the effect saturating at $50 \mathrm{ng} / \mathrm{ml}$. BDNF was used at $10 \mathrm{ng} / \mathrm{ml}$ and GDNF at $20 \mathrm{ng} / \mathrm{ml}$ (error bars represent SEM) (Shh, $p<$ 0.001 at 50 and $250 \mathrm{ng} / \mathrm{ml}$; BDNF, no significance; GDNF, $p<0.05$ ). Note that the plating density used in this experiment was twice that used in Figure 2.

1991; Krieglstein et al., 1995), we tested the ability of Shh to protect $\mathrm{TH}^{+}$cells in E14 rat mesencephalon explants from the effects of $\mathrm{MPP}^{+}$. As shown in Figure 8, the presence of Shh in cultures treated for $48 \mathrm{hr}$ with $\mathrm{MPP}^{+}$significantly increased the numbers of $\mathrm{TH}^{+}$cells that were observed in culture after removal of the $\mathrm{MPP}^{+} . \mathrm{MPP}^{+}$treatment caused a $>90 \%$ reduction in the numbers of $\mathrm{TH}^{+}$cells compared with non-MPP ${ }^{+}$-treated control cultures, whereas incubation with Shh protected the $\mathrm{TH}^{+}$cells so that only a $65 \%$ reduction in $\mathrm{TH}^{+}$cells occurred after $\mathrm{MPP}^{+}$ treatment. Thus, the addition of Shh resulted in a net 3.5 -fold increase in $\mathrm{TH}^{+}$cells after $\mathrm{MPP}^{+}$treatment versus controls. Sister cultures tested for ${ }^{3} \mathrm{H}$-DA transport demonstrated a sevenfold increase in transport in Shh-treated cultures versus controls (data not shown).

Shh was significantly more active in protecting $\mathrm{TH}^{+}$cells from the effects of $\mathrm{MPP}^{+}$than the other growth factors tested: GDNF (Lin et al., 1993) and BDNF (Hyman et al., 1991) (Shh, $p<0.001$ at 50 and $250 \mathrm{ng} / \mathrm{ml}$; BDNF, no significance; GDNF, $p<0.05)$. In the serum-free conditions used in these experiments, none of the other growth factors tested showed as significant a level of $\mathrm{TH}^{+}$ cell protection from $\mathrm{MPP}^{+}$toxicity as Shh, even when tested at levels previously shown to be optimal for neuroprotection (Fig. 8).

\section{DISCUSSION}

\section{Shh is neurotrophic for various ventral neurons}

The hypothesis that Shh may play roles in the nervous system in addition to its initial function in neural tube ventralization was first suggested by the observation that Shh expression in ventral neural tissue along the entire neuraxis continues well past the period during which phenotypic specification has occurred (Ech- 
elard et al., 1993). Moreover, preliminary evidence generated in our laboratory indicates the presence of significant levels of Shh mRNA in specific regions of the adult human CNS (e.g., spinal cord and substantia nigra) (P. Jin, unpublished observations). We report here the first evidence that Shh can indeed exert effects independent of its induction and patterning activity.

Unlike its role at earlier stages of neural development, this novel neurotrophic activity acts on postmitotic neurons rather than on dividing progenitor cells. Although the general trophic effect is apparent in a number of CNS regions (Figs. 2, 5-7), there are both differences and similarities in the effects observed among the regions examined. Given the fact that Shh is necessary for the induction of both spinal motor neurons and midbrain dopaminergic neurons, one might predict that Shh would subsequently be trophic for these cells. Strikingly, Shh is a very potent trophic factor for the midbrain dopaminergic neurons (Fig. 2), but in the cultures of ventral spinal neurons no such effect on motor neurons was observed. Thus there is no direct correlation between the neuron phenotypes induced by Shh and those supported by Shh in a trophic manner. Interestingly, a common feature among the three CNS regions examined was the trophic effect for GABAergic neurons (Figs. 5-7). Although it is not obvious whether these specific $\mathrm{GABA}^{+}$populations are directly or indirectly induced by Shh during early development (cf. Pfaff et al., 1996), it is plausible that the trophic actions on these neurons are direct.

It is important to note that the neurotrophic effects reported herein are not lacking in specificity. For example, neurons of the peripheral nervous system show no survival in response to Shh administration, and preliminary studies of cultures derived from E15-16 dorsal CNS regions (e.g., neocortex and dorsal spinal cord) show high baseline levels of neuron survival with no significant response to exogenous Shh application (J. Ott and N. Mahanthappa, unpublished observation). Thus there appears to be a general restriction of the trophic effects of Shh to regions of the CNS specified by Shh, but the actual targets of trophic activity need not encompass the phenotypes whose induction is Shh dependent. Nevertheless, the fact that Shh also protects neurons from toxic insult (Fig. 8) suggests previously unforeseen therapeutic roles for Shh as well.

\section{Possible mechanisms of Shh action}

As stated above, the neurotrophic effect of Shh observed in these cultures is not attributable to the stimulation of proliferation. One could argue, however, that the observed effects are indirect. In one scenario, Shh may act on a non-neuronal cell that in turn responds by secreting a neurotrophic factor. We observed no sign of astrocytes in any of our neural cultures, either by morphology or by staining for GFAP. Furthermore, in the purely neuronal cultures established from the midbrain, $p t c$ is greatly upregulated in response to Shh, and thus the reported survival effects must be attributable to a response by neurons (Fig. 4C).

In another scenario, it is possible that Shh acts directly on some or all of the neurons, but the response is to secrete another factor(s) that actually possesses the survival activity. For example, Shh has been shown to induce the expression of TGF $\beta$ family members such as Bone morphogenetic proteins in vivo (Laufer et al., 1994; Levin et al., 1995), and these proteins are trophic for midbrain dopaminergic neurons (Krieglstein et al., 1995). That induced expression of TGF $\beta \mathrm{s}$ is the trophic mechanism seems unlikely, because exogenous TGF $\beta$ s show only modest trophic activity in our culture system, and the presence of neutralizing, anti-pan-TGF $\beta$ antibodies failed to inhibit the neurotrophic ef- fects of Shh. Thus, at a minimum, Shh supports the survival of a subset of ventral CNS neurons. The mechanism by which Shh supports neuron survival is yet to be determined. Although we favor the hypothesis that these trophic effects are direct, it remains possible that the survival response is attributable to Shhinduced expression of a secondary trophic factor.

As in the case of many secreted peptide factors, it now appears that Shh has activities that can vary greatly, depending on the spatiotemporal context in which the factor is expressed. Although it was initially thought that the primary role of Shh in the CNS is in early patterning events that are critical to phenotypic specification, it is now clear that Shh can also contribute to the survival and maturation of these CNS regions. Interestingly, the cell types acted on in these two distinct roles of Shh do not necessarily overlap. Thus a more thorough understanding of this multifaceted molecule will require a better understanding of its patterns of expression beyond early embryogenesis. Moreover, it will be critical to ascertain the significance of the trophic effects of Shh in vivo.

\section{REFERENCES}

Altman J, Bayer SA (1995) Atlas of prenatal rat brain development. Boca Raton, FL: CRC.

Banerjee A, Roach MC, Trcka P, Luduena RF (1990) Increased microtubule assembly in bovine brain tubulin lacking the type III isotype of $\beta$-tubulin. J Biol Chem 1990:1794-1799.

Bumcrot DA, Takada R, McMahon AP (1995) Proteolytic processing yields two secreted forms of Sonic hedgehog. Mol Cell Biol 15:2294-2303.

Camu W, Henderson CE (1992) Purification of embryonic rat motoneurons by panning on a monoclonal antibody to the low-affinity NGF receptor. J Neurosci Methods 44:59-70.

Cerruti C, Walther DM, Kuhar MJ, Uhl GR (1993) Dopamine transporter mRNA expression is intense in rat midbrain neurons and modest outside midbrain. Mol Brain Res 18:181-186.

Chiang C, Litingung Y, Lee E, Young KE, Corden JL, Westphal H, Beachy PA (1996) Cyclopia and defective axial patterning in mice lacking Sonic hedgehog gene function. Nature 383:407-413.

Ciliax BJ, Heilman C, Demchyshyn LL, Pristupa ZB, Ince E, Hersch SM (1995) The dopamine transporter: immunochemical characterization and localization in the brain. J Neurosci 15:1714-1723.

Denis-Donini S, Glowinski J, Prochiantz A (1984) Glial heterogeneity may define the three dimensional shape of mouse mesencephalic DA neurons. Nature 307:641-643.

Di Porzio U, Daguet M-C, Glowinski J, Prochiantz A (1980) Effect of striatal cells on in vitro maturation of mesencephalic dopaminergic neurons grown in serum-free conditions. Nature 288:370-373.

Echelard Y, Epstein DJ, St-Jacques B, Shen L, Mohler J, McMahon JA, McMahon AP (1993) Sonic hedgehog, a member of a family of putative signaling molecules, is implicated in the regulation of CNS polarity. Cell 75:1417-1430.

Ericson J, Thor S, Edlund T, Jessell TM, Yamada T (1992) Early stages of motor neuron differentiation revealed by expression of homeobox gene Isl-1. Science 256:1555-1560.

Ericson J, Muhr J, Placzek M, Lints T, Jessell TM, Edlund T (1995) Sonic hedgehog induces the differentiation of ventral forebrain neurons: a common signal for ventral patterning within the neural tube. Cell 81:747-756.

Ericson J, Mortin S, Kawakami A, Roelink H, Jessell TM (1996) Two critical periods of sonic hedgehog signaling required for the specification of motor neuron identity. Cell 87:661-673.

Fietz MJ, Concordet J-P, Barbosa R, Johnson R, Krauss S, McMahon AP, Tabin C, Ingham PW (1994) The hedgehog gene family in Drosophila and vertebrate development. Development [Suppl] 120:43-51.

Forno LS, DeLanney LE, Irwin I, Langston JW (1993) Similarities and differences between MPTP-induced parkinsonism and Parkinson's disease: neuropathologic considerations. Adv Neurol 60:600-608.

Goodrich LV, Johnson RL, Milenkovic L, McMahon JA, Scott MP (1996) Conservation of the hedgehog/patched signaling pathway from flies to mice: induction of a mouse patched gene by hedgehog. Genes Dev 10:301-312.

Hyman C, Hofer M, Barde Y-A, Juhasz M, Yancopoulos GD, Squinto SP, 
Lindsay RM (1991) BDNF is a neurotrophic factor for dopaminergic neurons of the substantia nigra. Nature 350:230-232.

Hyman C, Juhasz M, Jackson C, Wright P, Ip NY, Lindsay RM (1994) Overlapping and distinct actions of the neurotrophins BDNF, NT-3, and NT-4/5 on cultured dopaminergic and GABAergic neurons of the ventral mesencephalon. J Neurosci 14:335-347.

Hynes MA, Gitt M, Barondes SH, Jessell TM, Buck LB (1990) Selective expression of an endogenous lactose-binding lectin gene in subsets of central and peripheral neurons. J Neurosci 10:1004-1013.

Hynes MA, Porter JA, Chiang C, Chang D, Tessier-Lavigne M, Beachy PA, Rosenthal A (1995) Induction of midbrain dopaminergic neurons by Sonic hedgehog. Neuron 15:35-44.

Kawaguchi Y, Wilson CJ, Augood SJ, Emson PC (1995) Striatal interneurones: chemical, physiological and morphological characterization. Trends Neurosci 18:527-535.

Kopin IJ, Markey SP (1988) MPTP toxicity: implications for research in Parkinson's disease. Annu Rev Neurosci 11:81-96.

Krieglstein K, Suter-Crazzolara C, Fischer WH, Unsicker K (1995) TGF $\beta$ superfamily members promote survival of midbrain dopaminergic neurons and protect them against MPP+ toxicity. EMBO J 14:736-742.

Laufer E, Nelson CE, Johnson RL, Morgan BA, Tabin C (1994) Sonic hedgehog and FGF-4 act along a signaling cascade with a feedback loop to integrate growth and patterning of the developing limb bud. Cell 79:993-1003.

Lee JJ, Von Kessler DP, Parks S, Beachy PA (1992) Secretion and localized transcription suggest a role in positional signaling for products of the segmentation gene hedgehog. Cell 71:33-50.

Levin M, Johnson RL, Stern CD, Kuehn M, Tabin C (1995) A molecular pathway determining left-right asymmetry in chick embryogenesis. Cell 82:803-814.

Lin L-FH, Doherty DH, Lile JD, Bektesh S, Collins F (1993) GDNF: a glial cell line-derived neurotrophic factor for midbrain dopaminergic neurons. Science 260:1130-1132.

Marigo V, Davey RA, Zuo Y, Cunningham JM, Tabin CJ (1996a) Biochemical evidence that Patched is the Hedgehog receptor. Nature 384:176-179.

Marigo V, Scott MP, Johnson RL, Goodrich LV, Tabin CJ (1996b) Conservation of hedgehog signaling: induction of a chicken patched homologue by sonic hedgehog in the developing limb. Development 122:1225-1233.

Marti E, Bumcrot DA, Takada R, McMahon AP (1995a) Requirement of $19 \mathrm{~K}$ sonic hedgehog for induction of distinct ventral cell types in CNS explants. Nature 375:322-325.
Marti E, Takada R, Bumcrot DA, Sasaki H, McMahon AP (1995b) Distribution of sonic hedgehog peptides in the developing chick and mouse embryo. Development 121:2537-2547.

Masuko S, Nakajima S, Nakajima Y (1992) Dissociated high-purity dopaminergic neuron cultures from the substantia nigra and the ventral tegmental area of the postnatal rat. Neuroscience 49:347-364.

Mohler J, Vani K (1992) Molecular organization and embryonic expression of the hedgehog gene involved in cell-cell communication in segmental patterning of Drosophila. Development 115:957-971.

Nusslein-Volhard C, Wieschaus E (1980) Mutations affecting segment number and polarity in Drosophila. Nature 287:795-801.

Pfaff SL, Mendelsohn M, Stewart CL, Edlund T, Jessell TM (1996) Requirement for LIM homeobox gene Isl1 in motor neuron generation reveals a motor neuron-dependent step in interneuron differentiation. Cell 84:309-320.

Porter JA, Ekker SC, Young KE, Von Kessler DP, Lee JJ, Moses D, Beach PA (1995) The product of hedgehog autoproteolytic cleavage active in local and long-range signaling. Nature 374:363-366.

Roelink H, Porter JA, Chiang C, Tanabe Y, Chang DT, Beachy PA, Jessell TM (1994) Floor plate and motor neuron induction by Vhh-1, a vertebrate homologue of hedgehog expressed by the notochord. Cell 76:761-775.

Shimoda K, Sauve Y, Schwartz JP, Commissiong JW (1992) A high percentage yield of tyrosine hydroxylase-positive cells from rat E14 mesencephalic cell culture. Brain Res 586:319-331.

Stone DM, Hynes M, Armanini M, Swanson TA, Gu Q, Johnson RL, Scott MP, Hooper JE, Sauvage FD, Rosenthal A (1996) The tumorsuppressor gene patched encodes a candidate receptor for Sonic hedgehog. Nature 384:129-134.

Tabata T, Eaton S, Kornberg TB (1992) The Drosophila hedgehog gene is expressed specifically in posterior compartment cells and is a target of engrailed regulation. Genes Dev 6:2635-2645.

Tanabe Y, Roelink H, Jessel TM (1995) Induction of motor neurons by sonic hedgehog is independent of floor plate. Curr Biol 5:651-658.

Tsuchida T, Ensini M, Morton SB, Baldassare M, Edlund T, Jessell TM, Pfaff SL (1994) Topographic organization of embryonic motor neurons defined by expression of LIM homeobox genes. Cell 79:957-970.

Wang MZ, Jin P, Bumcrot DA, Marigo V, McMahon AP, Wang EA, Woolf T, Pang K (1995) Induction of dopaminergic neuron phenotype in the midbrain by sonic hedgehog protein. Nature Med 1:1184-1188.

Wilkinson, DG (1992) Whole mount in situ hybridization of vertebrate embryos. In: In situ hybridization: a practical approach (Wilkinson DG, ed), pp 75-83. Oxford: IRL. 